\title{
La representación de lo incaico en Tradiciones peruanas
}

\section{Representation of the Incas in Tradiciones peruanas}

Arcadio Antonio Bolaños Acevedo*

RESUMEN: el objetivo del presente artículo es analizar la representación de lo indígena, comparando la figura idealizada de los incas versus la imagen negativa y despectiva del indígena actual. Para ello, es esencial leer críticamente las Tradiciones peruanas de Ricardo Palma, principal escritor peruano del siglo XIX, época clave para la consolidación de Perú como una nueva nación independiente. Es en este contexto en el que los textos de Palma cumplen una función fundamental al imaginar el pasado de los incas como algo glorioso y distante, a la vez que se menosprecia al indígena actual. Este artículo se centra en el conflicto que produce esta dicotomía entre incas e indígenas, a la vez que indaga sobre las consecuencias negativas de una comunidad imaginada que se discriminaba a sí misma en el pasado y que lo continúa haciendo en el presente.

Palabras Clave: Comunidad imaginada, Ricardo Palma, Tradiciones peruanas, Inca, Indio, Siglo XIX.

ABSTRACT: The object of this article is to analyze the representation of the indigenous people, comparing the idealized vision of the Incas versus the negative and dismissive treatment of current indigenous people. The first step to accomplish this goal is to read Tradiciones peruanas critically. The author of these texts, Ricardo Palma, was the most important Peruvian writer in the $19^{\text {th }}$ century, a key period for the consolidation of Peru as a new independent nation. It is in this context that the texts of writer Ricardo Palma play a fundamental role in imagining the past of the Incas as something glorious and distant, while the current indigenous population is belittled. This article focuses on the conflict produced by this dichotomy between Incas and indigenous people, while paying attention to the negative consequences of an imagined community that discriminated itself in the past and continues to do so in the present.

KeYworDS: Imagined Community, Ricardo Palma, Tradiciones peruanas, Inca, Indigenous, $19^{\text {th }}$ century.

Recibido: 20 de diciembre de 2019

Aceptado: 21 de mayo de 2020

University of California-Davis, Estados Unidos (bolanosacevedo@ucdavis.edu). 


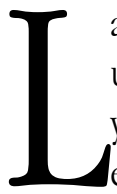

as Tradiciones peruanas (1872) de Ricardo Palma se consideran una de las obras literarias más influyentes, ampliamente conocidas y leídas en el Perú y en otros países de la región. A medio camino entre la crónica, la narrativa breve y la anécdota episódica revestida de cierto costumbrismo, las tradiciones de Palma parecen haberse instalado definitivamente en un género aparte, que las coloca por encima de las clasificaciones convencionales. Es por ello que pueden ser analizadas e interpretadas desde múltiples perspectivas. Utilizar un enfoque histórico, literario o sociológico, lejos de causar contradicción, sirve para entender mejor la obra del reconocido autor.

El siglo XIX es el momento en el que Perú y otros países latinoamericanos se consolidan como naciones soberanas e independientes. Esta es también una época en la que resulta fundamental crear el concepto de patria. Benedict Anderson ha explicado que los países son comunidades imaginadas: "I propose the following definition of the nation: it is an imagined political community" (2006 [1993]: 49), ${ }^{1}$ es decir, creaciones arbitrarias; es lógico, por tanto, inventar símbolos como banderas o himnos que permitan a los ciudadanos sentir que forman parte de una unidad mayor, de algo más grande que ellos mismos.

En este sentido, Ricardo Palma es un autor que participa de manera fundamental en la invención del Perú. La extensa labor manifestada en sus tradiciones es un ejemplo de su interés por lo peruano. Resulta pertinente comprobar que en sus escritos quedan reflejados diversos momentos de la historia del Perú, enfocados desde muy diversos ángulos y a través de una amplia gama de lugares y personajes.

También hay que señalar que la difusión de las obras de Palma en su momento es a través de los periódicos. Se debe recordar que "el periódico, junto con la novela, fueron medios a través de los cuales fue posible representarse el tipo de comunidad imaginada que es la nación" (Méndez 1996: 19). Gracias a esto, las tradiciones de Palma alcanzan a un público

1 "Propongo la siguiente definición de nación: es una comunidad política imaginada" (traducción del editor). 
más numeroso, a un público que no es exclusivamente académico ni experto en literatura.

Prácticamente la totalidad de los relatos de Palma se centran en la época posterior a la Conquista, el virreinato y las primeras décadas de la república peruana. No obstante, también llegó a escribir algunas tradiciones en donde lo incaico y lo andino están presentes. Desperdigadas a lo largo de varias series de tradiciones, pueden encontrarse las siguientes: "Palla Huarcuna", "La gruta de las maravillas", "La Achirana del Inca", "El que pagó el pato", "Los Caciques Suicidas", "Ollantay" y "Los incas ajedrecistas"; es decir, apenas 7 de las 453 tradiciones que el autor escribió a lo largo de varios años.

Otro escritor podría haber prescindido del todo de estas historias de carácter autóctono; sin embargo, en el caso de Palma, no se trata de una producción gratuita. Por lo tanto, podría afirmarse que la representación de lo incaico en Tradiciones peruanas sintetiza un largo proceso histórico de consolidación del Perú como comunidad imaginada.

América y Perú no existen para los ojos de los europeos, ni del resto del mundo, sino hasta fines del siglo XV. El primer encuentro entre Europa y América se produjo bajo la mirada de Cristóbal Colón; en sus diarios sobre la primera expedición, la descripción e interpretación que se lleva a cabo acerca del Nuevo Mundo es especialmente sugerente. Estos primeros escritos "Versan sobre cosas que se han visto la primera vez. Y en los lectores europeos de entonces, como en nosotros hoy, ejercen hechizo novelesco" (Meléndez 1970: 27). Efectivamente, lo que eran simplemente relaciones y crónicas en siglos anteriores, se han convertido hoy en textos de interés literario.

Es importante señalar que Colón construye mentalmente este Nuevo Mundo, guiado por algunos preconceptos erróneos, pero también por sus observaciones y experiencias personales. América y todos sus territorios, incluyendo la futura nación peruana, pasan entonces a ser un lugar posible de imaginar a partir de las reflexiones iniciales del almirante.

Lo primero que hace Colón al pisar tierra es tomar posesión del territorio recién descubierto: "y dixo que le diesen por fe y testimonio cómo 
él por ante todos tomava, como de hecho tomó, possessión de la dicha isla por el Rey e por la Reina, sus señores" (Colón 1989: 42). Este acto, además de realizarse con las banderas e insignias reales, incluye también al escribano de la armada y los respectivos documentos legales que legitiman las palabras de Colón. De esta forma, el Nuevo Continente queda conquistado por escrito, literariamente, por así decirlo, antes de haber sido sometido de facto. Es decir, lo primero que tiene lugar es la documentación legal que hacía de América una inmensa colonia ibérica. Sin lugar a dudas, América, y por lo tanto el Perú, existe para los europeos gracias a la palabra escrita, presente en crónicas o en cartas, tan llenas de fantasía como cualquier obra literaria, escritas por los primeros exploradores y conquistadores.

La primera fuente de información proviene de Colón, a él se le debe la imagen del indio pobre, desnudo, indefenso, sin armas, ignorante, etc. La discusión sobre la naturaleza del indio se sostiene sobre la base de estas primeras expresiones literarias; de este modo, no solamente lo literario juega un papel clave en la Conquista, sino también en la construcción de la identidad americana, en la forma de definir al "otro". Entonces, la consecuencia lógica del proceso histórico iniciado a fines del siglo XV es el retorno a lo literario como una manera de definir y describir la realidad; en efecto, el nuevo país, el Perú, solamente será imaginado principalmente a través de la literatura, y las Tradiciones peruanas constituirán el ejemplo perfecto.

También es relevante señalar que a lo largo de los años, durante el periodo de conquista y luego en el virreinato, distintos cronistas crean y recrean el territorio peruano a través de sus libros. Así, por ejemplo, Francisco de Xerez escribió la Verdadera relación de la conquista del Perú en 1534, poco tiempo después de la captura de Atahualpa en Cajamarca; también son útiles los aportes de Pedro Cieza de León, otro importante cronista.

En el siglo XIX, Palma tiene la oportunidad de dejar para la posteridad su propia visión del Perú. Aunque el ilustre autor no podría haberlo adivinado, sus Tradiciones peruanas alcanzaron la categoría de clásicos 
en el ámbito literario peruano, y no solamente se convirtieron en lectura obligatoria en los colegios sino que pasaron a ser uno de los principales referentes de la literatura peruana. No hay duda de que la imagen que se tiene sobre el pasado peruano está, en buena medida, marcada por las imágenes que Palma desarrolló en sus escritos. El criollismo, las tapadas limeñas, los virreyes, etc., forman parte del imaginario colectivo de todos los peruanos. Esto sucede porque Palma escribe en un siglo que define al país; varias décadas después de la independencia, Palma es uno de los sujetos que imaginará la comunidad en la que vive, y por tanto permitirá que otros se imaginen, y se identifiquen, como ciudadanos del Perú.

La comunidad imaginada, según Benedict Anderson, se plantea como un concepto abstracto antes que una realidad concreta. En efecto, un país no se trata de un territorio delimitado sino de la gente que lo compone y que se considera habitante de dicha nación.

Anderson también señala algunas de las formas por las que se legitima esta idea de nación, entre ellas, un sistema de representación, es decir, una lengua. En este sentido, la literatura siempre ha jugado un rol esencial. Cuando César Augusto le encargó a Virgilio que escribiera la Eneida, lo hizo con una sola razón en mente: ennoblecer el origen de Roma, y por lo tanto, fortalecer en todos los ciudadanos el orgullo de formar parte del glorioso Imperio Romano. Del mismo modo, para muchos, Italia empezó a existir gracias, en buena medida, a la Divina Comedia de Dante Alighieri. Si bien la obra de Palma difiere en estilo de estos clásicos inmortales, no se le debe restar importancia. Al fin y al cabo, las Tradiciones peruanas también sirvieron, como tantas otras obras literarias en el mundo, para unificar a una población en torno a una misma idea: un país en común.

Resulta especialmente interesante observar que las Tradiciones peruanas incluyen una gran variedad de estampas costumbristas de la Lima virreinal, o relatos que la crítica especializada podría considerar influenciados por el Romanticismo, o anécdotas sobre los libertadores o personajes de gran fama, pero son muy escasas las tradiciones sobre lo incaico o, en general, sobre todo lo que se refiere a la época precolombina. 
Habría que preguntarse en qué medida la construcción de la idea de país puede permitirse el lujo de obviar su pasado y su legado histórico. El aparente descuido de Palma obedece a un contexto sociopolítico particular, en el que las clases dominantes miran con malos ojos a la población indígena: "El pesimismo de los aristócratas decimonónicos no estaba tanto en relación a su propia clase sino al resto del país; a un pueblo que veían muy por debajo de ellos, inculto e irremediable" (Méndez 1996: 2). Si bien Palma no pertenece necesariamente a este grupo aristocrático, muchas de sus sensibilidades sí parecen coincidir con él.

El pesimismo está presente, por ejemplo, en "Palla Huarcuna", una tradición que narra un episodio de la vida de "Túpac-Yupanqui, el rico de todas las virtudes, como lo llaman los haravicus del Cuzco" (Palma 1863a: 11). En principio parece haber aquí tan sólo una simple historia amorosa, el inca se enamora de Palla Huarcana pero ella lo traiciona y provoca un final trágico. No obstante, está muy presente la idea del destino; en efecto, se vaticina el fin del Tahuantinsuyo y la llegada de los conquistadores españoles, y se remarca la inevitabilidad de ese futuro.

Hay un trasfondo bélico en "Palla Huarcuna" que llama la atención: "La victoria ha acompañado a su valiente ejército, y la indómita tribu de los pachis se encuentra sometida" (Palma 1863a: 11). El enfoque que le da Palma a las tribus guerreras andinas es muy diferente al enfoque de los cronistas españoles, y bastante alejado de las primeras declaraciones de Cristóbal Colón.

La primera descripción del almirante subestima a la población indígena: "todo tomavan y daban de aquello que tenían de buen voluntad, mas me pareció que era gente muy pobre de todo. Ellos andan todos desnudos, como su madre los parió, y también las mugeres" (Colón 1989: 43). Pero, además de ser pobres en todo, es decir, como antepasados históricos y simbólicos de la permanente pobreza latinoamericana que hoy parece definir más a estos países que cualquier otra cosa, se trata de gente indefensa: "Ellos no traen armas ni las cognoçen, porque les amostré espadas y las tomavan por el filo y se cortavan con ignorancia" (Colón 
1989: 43). Nuevamente, el indígena o indio es presentado como un sujeto ignorante, que no tiene nada de amenazante.

Es importante señalar que en estos primeros encuentros está la base de lo que sería después la relación entre los conquistadores y los indígenas; no en vano Xerez y Cieza narran la asombrosa facilidad con la que apresan al inca. Además, este tipo de representaciones seguirá estando presente en la mente de los europeos, por ejemplo, el concepto de "buen salvaje" de Rousseau no existiría sin este tipo de representaciones; solamente se puede hablar de un buen salvaje sobre la base de su condición de ser indefenso y potencialmente bueno (es decir, un sujeto que aceptará la religión y el idioma que el hombre europeo le imponga). Hay principalmente dos formas claves de interpretación del indio, que corresponderían a Las Casas y a Ercilla: "Fray Bartolomé de las Casas (1474-1566) es el predecesor de Rousseau al mirar al hombre primitivo como encarnación del bien y la inocencia" (Meléndez 1970: 17).

En cambio, Palma en cierto modo contradice a los europeos españoles en esta tradición, presentando una batalla semejante a cualquiera que pudiese ocurrir en suelo europeo; tal vez, en este aspecto, su intención como tradicionista lo acerca a Alonso de Ercilla, que en su obra La Araucana reivindica al indígena como poderoso enemigo y rival.

Palma entrega al lector un ingenioso desenlace: "El gran sacerdote, al verlo moribundo, ha dicho que se acerca la ruina del imperio de Manco, y que otras gentes vendrán, en piraguas de alto bordo, a imponerle su religión y sus leyes" (Palma 1863a: 11). Se hace explícita esta suerte de profecía sobre el futuro. "Fray Bartolomé de las Casas hablaría de un proceso ya en algunos lugares consumado e irreversible: el de la destrucción de las Indias" (Pastor 1983: 17); ciertamente, en esta tradición, el futuro del imperio incaico es muy claro. Asimismo, "El inicio de un proceso de destrucción de las Indias coincidiendo con la llegada de Colón al Caribe es un hecho indiscutible" (1983: 18). Las últimas líneas de esta tradición marcan dramáticamente la inevitabilidad del destino: "En vano alzáis vuestras plegarias y ofrecéis sacrificios, ioh hijas del Sol!, porque el augurio se cumplirá" (Palma 1863a: 12). 
Tanto la autoridad imperial como la religiosa (inca y chamanes) tienen la sabiduría de aceptar el fin del Tahuantinsuyo. "El indio es, pues, aceptado en tanto paisaje y gloria lejana. Es 'sabio' si es pasado y abstracto, como Manco Cápac. Es bruto o ‘estólido’ e ‘impuro’ y ‘vándalo’ si es presente" (Méndez 1996: 12). En esta tradición, en efecto, el inca es el símbolo de esa gloria pasada.

"La gruta de las maravillas", tiene como protagonista a "Mayta-Cápac, llamado el Melancólico, cuarto Inca del Cuzco" (Palma 1863b: 32); en esta ocasión se narra el combate contra Huascari y la consiguiente conquista de la región de los chumpihuilcas. Pese a la mención de los "auquis o dioses tutelares" (Palma 1863b: 33), el discurso tácito configura una retórica eminentemente española, en donde incluso llegan a reproducirse algunas de las imágenes de cronistas e historiadores.

En los primeros párrafos de esta tradición se relatan las actividades de Mayta-Cápac: "después de vencer a los rebeldes de Tiahuanaco y de dilatar su imperio hasta la laguna de Paria, dirigióse a la costa y realizó la conquista de los fértiles valles de Arequipa y Moquegua" (Palma 1863b: 32). Es interesante observar que en esta tradición, en donde los protagonistas representan el poderío incaico, se sigue un evidente modelo europeo conquistador.

Después de la conquista, proteger a los indios derrotados era una opción que los españoles no estaban dispuestos a aceptar. Y estos indígenas vencidos sólo podían ser conocidos en Europa a través de las crónicas y documentos que los primeros exploradores escribieron. Así, en esta tradición, los incas parecen asumir el rol de los europeos conquistadores, con todo lo que esto conlleva (poder, agencia, triunfo, etc.). Al mismo tiempo, este modelo narrativo permite establecer una alianza tácita entre los lectores peruanos y el público europeo, que quedan embelesados frente a una realidad de batallas y conquistas, aunque aquí la única fuente de información disponible ya no es exclusivamente la crónica sino también la tradición de Palma.

Tras la hazaña de Mayta-Cápac, se cuenta lo siguiente: "dejó admirados a los vasallos de Huascari e infundió en sus ánimos tan supersticioso 
terror, que muchos, arrojando las armas, emprendieron una fuga vergonzosa" (Palma 1863b: 33). Es muy grande la coincidencia entre este párrafo y la imagen que, por ejemplo, presenta Colón en sus diarios; la cobardía de los indios es un tema frecuentemente tratado desde una perspectiva occidental.

Para Cieza, que visita Perú bastante tiempo después de la famosa proeza de Pizarro, los indios del Perú son 'domésticos'; de hecho, afirma lo siguiente: "Los del Perú sirven bien y son domables porque tienen más razón que éstos y porque todos fueron subjetados por los reyes ingas" (Cieza 1985: 78). Cieza llega a una realidad ya consumada, la conquista ya es un hecho, y él se dedica a explicar la sumisión de estos indios que ya no representan ninguna amenaza para los conquistadores, de igual modo que los primeros indios que Colón vio eran absolutamente indefensos.

Esta dicotomía entre el inca poderoso y soberano versus el indígena dócil y subyugado va más allá de la literatura y persiste en el imaginario colectivo de la sociedad peruana. Aunque en una primera lectura, "La gruta de las maravillas" se puede entender como una simple historia llena de detalles bélicos, en realidad se trata de una síntesis de varias ideas de historiadores y cronistas de la península ibérica, una síntesis que se manifiesta sutilmente a través de la capacidad narrativa de Palma.

"La Achirana del Inca" tiene de protagonista al inca Pachacutec, que luego de subyugar la región de Ica, descrita como "feraz territorio" (Palma 1863b: 33) se enamora de una inocente joven; ella, sin embargo, no tiene interés en él, afortunadamente el generoso inca la disculpa y le otorga a ella y a su poblado un canal de riego, es decir, la achirana. Si bien ésta parece ser una simple narración sobre un amorío fugaz, vale la pena resaltar los puntos en común que tiene con estereotipos literarios del teatro y la poesía españoles del Siglo de Oro; la joven es virtuosa y discreta, y la actitud de Pachacutec tiene más que ver con la de un rey de una obra de Lope de Vega que con la de un verdadero inca.

Como en muchas otras tradiciones, Ricardo Palma incluye en "La Achirana del Inca" datos históricos y fechas: "En 1412, el Inca Pachacutec, acompañado de su hijo el príncipe imperial Yupanqui y de su hermano 
Capac-Yupanqui, emprendió la conquista del valle de Ica" (Palma 1863b: 33). Nuevamente la idea de la conquista está firmemente instalada en esta tradición.

La Conquista precede al imperio, pero como bien señala Nebrija (1980) "siempre la lengua fue compañera del imperio". No basta con la posesión de un territorio, también debe haber una uniformización en cuanto a idiomas. Cuando se hizo necesaria la implementación masiva de la lengua general del Cuzco, Cieza señaló lo siguiente: "Y para que más fácilmente conozcan el error en que han vivido, y conoscido abracen nuestra santa fe, se ha hecho arte para hablar su lengua con gran industria, para que se entiendan los unos y los otros" (1985: 168). Resulta evidente la necesidad de una misma lengua para poder evangelizar y administrar a un pueblo que se encuentra disperso a lo largo de una inmensa cantidad de tierras. Probablemente, "La Achirana del Inca" presenta la conquista realizada por el Tahuantinsuyo como algo glorioso porque, al fin y al cabo, significa la unificación. Un territorio unido y con una misma lengua es lo que desean los españoles, de otro modo dominarlo y gobernarlo hubiese sido mucho más difícil. Y ese territorio unido y con una misma lengua se convertirá en la futura República del Perú.

"El que pagó el pato" detalla las peripecias de Titu-Atauchi, hermano de Atahualpa; inmediatamente después de la ejecución de Atahualpa, Titu-Atauchi decide vengarse de los jueces que autorizaron la muerte de su hermano: "Titu-Atauchi había jurado vengar la sangre de su hermano en el primero de sus verdugos que tomara prisionero" (Palma 1863b: 215). Hubo 24 jueces españoles que intervinieron en el proceso establecido en contra del gobernante del Tahuantinsuyo, 13 votaron a favor de la muerte del inca, y 11 en contra.

Uno de los aspectos más interesantes de esta tradición, es que Ricardo Palma se encarga de subrayar la injusticia de dicho proceso, y no escatima esfuerzos al afirmar que los jueces que apoyaron la sentencia de muerte merecían ser castigados, mientras que los jueces que intentaron conservarle la vida a Atahualpa eran dignos y honorables: "A este tirano manda Puchacamac que se le mate por matador del Inca" (Palma 1863b: 
216). El episodio de la muerte de Atahualpa es quizá una de las situaciones más estudiadas de la historia peruana, y está presente en la mente de todos los que han tenido clases de historia en el colegio. Lo importante es señalar que Palma toma una posición, y la defiende, y con eso es capaz de influir, en gran medida, en la opinión de sus lectores.

El triunfo de las huestes de Francisco Pizarro representa un momento clave e imprescindible en la historia. No obstante, España siempre sintió que debía encontrar una manera de legitimar la conquista, mediante la evangelización, al fin y al cabo, la fe católica era parte inseparable del pensamiento castellano. Desde el primer viaje de Cristóbal Colón, el deseo de evangelización estaba muy presente. Muchos historiadores y cronistas opinan que la Iglesia es imprescindible para el desarrollo de la sociedad colonial.

Legitimar la conquista significa enfocarse solamente en los aspectos positivos y tratar de olvidar los negativos. Por eso se debe justificar los errores y excesos cometidos por la Corona. Palma resume literariamente la conquista del Perú en un sólo momento, y la injusticia mayor en un sólo acto: la ejecución de Atahualpa. Así, el escritor peruano afirma lo siguiente: "a haber estado Hernando de Soto no se habría manchado la conquista con tan inicuo como estéril crimen" (Palma 1863b: 214). Resulta evidente que no es la conquista lo que se cuestiona en esta tradición, sino la falta de honor y la lamentable iniquidad que ocurre en el proceso judicial que termina imponiendo sobre el inca la pena capital.

Es evidente que hay individuos que no podrían formar parte de ciertos procesos, mucho menos de una conquista, si pensaran que no están haciendo lo correcto. El conquistador español, en un nivel básico, necesitaba pensar que la conquista era legítima, que se trataba de algo apropiado o correcto. También la Corona tenía la necesidad de justificar su presencia en América; después de todo, si algo se puede aprender de la historia, es que muchas veces los conquistadores (o las tiranías o las dictaduras o los gobiernos totalitarios) recurren a todo tipo de explicaciones e ideologías para legitimar sus acciones. En lugar de centrarse en otros temas, Palma 
se concentra en una sola injusticia; y mantiene siempre una mirada de respeto hacia esos primeros españoles.

"El que pagó el pato" es, al igual que varias crónicas y textos, y de manera extraoficial, una legitimación de la conquista. Sin embargo, Palma acepta y remarca los excesos cometidos por los conquistadores peninsulares. Las últimas líneas de esta tradición le dejan al lector un claro mensaje de venganza frustrada por parte de los pobladores andinos: "Los indios conservaban el garrote que sirvió para el suplicio de su monarca, y llamábanlo el palo maldito" (Palma 1863b: 216). Al final, nadie puede cuestionar la conquista, solamente se puede señalar el atropello y abuso de algunos, porque solamente algunos son los que realizan actos indignos en "El que pagó el pato". En esta tradición también se debe resaltar la frustración del pueblo autóctono del Perú.

En "Los caciques suicidas" se relata un hecho que se encuentra conectado con la captura de Atahualpa y el cuarto del rescate. "El cacique de Yanahuara tenía ya reunida inmensa cantidad de oro para contribuir al rescate de Atahualpa, cuando recibió la noticia de que los españoles habían dado muerte al soberano" (Palma 1863c: 238). Al enterarse de la noticia, el cacique esconde el oro y se deja morir.

Luego, otro cacique de la misma región minera decide desafiar las órdenes de Francisco Pizarro. Es significativo observar que este cacique es "testigo del envilecimiento de sus súbditos" (Palma 1863c: 239), es decir, los antiguos miembros del Tahuantinsuyo han perdido su antigua dignidad y orgullo. Este tipo de percepción coincide en gran medida con la opinión de ciertos cronistas. En Cieza, por ejemplo, no existe idealización alguna de la figura del indio. Algunos de los comentarios del cronista son bastante reveladores: "En todas las cosas son de poca constancia; no tienen vergüenza de nada ni saben qué cosa sea virtud y en malicias son muy astutos unos para con otros" (Cieza 1985: 92). En algunos casos presenta aspectos positivos y en otros negativos, dependiendo del grupo étnico que está ante sus ojos; para él, los indios no son salvajes inhumanos pero tampoco son cristianos civilizados. En más de una ocasión expresa su admiración por los incas: "Hicieron tan grandes cosas y tuvieron tan 
buena gobernación, que pocos en el mundo les hicieron ventaja" (Cieza 1985: 150). Hay una innegable dicotomía: el pasado glorioso del incario es digno de ser recordado y admirado, pero los descendientes de los incas no merecen ningún respeto por parte de los europeos. Este tipo de pensamiento marcaría la pauta para los escritores e intelectuales del siglo XIX, quienes "apelaron a una retórica de grandeza inca para despreciar lo indio" (Méndez 1996: 16). Exactamente lo mismo ocurre con Palma, quien rescata y celebra el pasado pero en cierto modo menosprecia el presente. "Pues si se idealiza o exalta el pasado, en este caso el más remoto, es justamente en compensación por lo que se ve negado en el presente" (Méndez 1996: 6). Y es que, en el presente, el indio (o el andino), parece estar estancado en un círculo vicioso de pobreza y subdesarrollo, que difícilmente podría formar parte del discurso de modernidad y progreso de Palma o de un candidato presidencial del siglo XXI.

Las tradiciones seleccionadas, en conjunto, reflejan una serie de hechos que se encuentran bastante desligados de la Lima del siglo XIX, a veces son más una especie de idealización del pasado, de un pasado que cada día es más remoto. En cambio, en las tradiciones ambientadas en una época más próxima a Palma, la imagen de lo autóctono es ciertamente distinta. Basta recordar tradiciones como "Carta canta" en donde los indios protagonistas son mostrados como seres torpes, desobedientes y de muy escasa inteligencia, su única virtud parece ser la facilidad para convertirse en objetos de burla y provocar la risa del patrón o bien del lector.

Más que una tradición habitual, "Ollantay" es una suerte de ensayo breve que Ricardo Palma realiza sobre la base del trabajo de un colega suyo. "Ollantay" es originalmente una obra teatral: "Entre los dramas escritos en quechua después de la conquista, el Ollantay es el de más méritos literarios" (Meléndez 1970: 33); por tanto, no resultará sorprendente que intelectuales de la talla de Palma se hayan interesado en él.

Las páginas de "Ollantay" son especialmente reveladoras, porque todo lo que se encuentra en ellas es expresión directa de la opinión de Palma. No hay personajes a través de los cuales se filtra la voz del autor, ni metáforas ni ficciones de por medio. Se trata de una reseña o comentario 
que Palma escribe para un investigador que se ha dedicado a estudiar el texto anónimo "Ollantay". Palma asevera lo siguiente: "Incuestionable es que la civilización de los imperios del Anahuac y Cuzco estuvo bastante avanzada para que estos pueblos hubieran tenido una literatura propia, original, verdadera expresión de las ideas y sentimientos de sus naturales" (Palma 1863d: 272). Ciertamente, la recopilación de relatos orales ha dado origen a trabajos tan exhaustivos como los del manuscrito de Huarochirí, pero lo cierto es que la oralidad también ha significado que prácticamente la totalidad de las leyendas, canciones e historias de la civilización incaica no hayan llegado hasta nuestros días.

Palma también comenta lo siguiente: "El yaraví, por ejemplo, especie de melancólico idilio, refleja por completo el carácter sombrío y soñador de la raza india" (Palma 1863d: 272). Aunque el autor no defina exactamente qué es ese carácter sombrío y soñador, éste pareciera ser uno de esos casos en los que el intento de elogio termina por convertirse en un término despectivo. El escritor peruano completa su idea del siguiente modo: "Uno de los caracteres distintivos de la poesía lírica entre los indígenas fue el tono filosófico y sentencioso de sus conceptos. Garcilaso nos ha transmitido algunas muestras de ella que justifican esta creencia. Y no sólo fue tal la índole de la poesía lírica entre los bardos del Perú, sino entre los del imperio azteca" (Palma 1863d: 272). Más allá del estudio literario, llama la atención que incas y aztecas sean comparados de esta manera.

Más adelante, Palma reflexiona sobre un aspecto literario de suma relevancia: "Si para constituir una literatura nacional bastarán la originalidad de imágenes, la traducción fiel de costumbres y caracteres y el trasunto del clima y del cielo bajo el cual se vive, preciso nos sería confesar que el drama Ollantay simboliza la poesía indígena en el Perú" (Palma 1863d: 273). Pero este tipo de poesía sería un trabajo de recopilación traducido al español sobre la base de transmisiones orales en quechua, lo que hace muy difícil catalogar a "Ollantay" como un verdadero ejemplo de "poesía indígena".

"Ollantay" brinda el marco ideal para la elaboración de ideas sobre lo indígena, y así, Palma critica a un grupo de literatos criollos, que pueden 
ser identificados como los predecesores del indianismo, porque a pesar de que "hayan pretendido crear una literatura indígena, vese en sus obras algo de amanerado, de poco espontáneo" (Palma 1863d: 273); además, declara que la influencia de la literatura peninsular es excesivamente obvia en estos trabajos (aunque, curiosamente, a Palma se le podría hacer esa misma acusación). De hecho, Meléndez afirma lo siguiente: "Casi todos los factores que habían de constituir en su momento a la novela indianista están ya en la literatura de los conquistadores y en la colonial" (17).

Estas reflexiones sobre la literatura, lo indígena y la creación de un arte que estuviese, al menos, parcialmente vinculado con el pasado precolombino del Perú, dejan en evidencia el malestar de la época, que el propio Palma prefiere omitir: "la prohibición explícita, para las poblaciones indígenas, de todo tipo de manifestaciones que pudiesen revivir la tradición inca [...]. A partir de entonces, serían los propios criollos quienes asumirían la reproducción de las tradiciones y la simbología incas" (Méndez 1996: 24). Además de conquistados y evangelizados, los indígenas han sido también enmudecidos, y lo que se sabe de ellos es escrito por la elite letrada limeña.

Finalmente, "Los incas ajedrecistas" es otra tradición que gira alrededor de la figura de Atahualpa. En ella, el ajedrez es el catalizador de una trágica muerte. Varios españoles, incluyendo a Hernando de Soto, se reunían para jugar ajedrez en las inmediaciones del recinto que sirvió como prisión a Atahualpa. "Honda preocupación abrumaría el espíritu del Inca en los dos o tres primeros meses de cautiverio" (Palma 1863d: 313); a pesar de estas preocupaciones, Atahualpa aprende a jugar ajedrez gracias solamente a su poder de observación, y en una partida permite que Hernando de Soto sea el ganador al darle una oportuna recomendación (del mismo modo, diversos historiadores señalan que, con su capacidad de observación, Atahualpa aprende solo y en muy poco tiempo la lengua de los conquistadores y logra comunicarse directamente con ellos). Como en muchas otras tradiciones, Palma se enfoca en lo anecdótico y así, detalla que el contrincante que Hernando de Soto derrotó fue después uno de los jueces que decidió votar a favor de la muerte del inca. La conclusión, 
típicamente irónica y humorística, es que el ajedrez provocó el "injustificable sacrificio de Atahualpa" (Palma 1863d: 313).

En "Los incas ajedrecistas" también están los primeros indicios de la estrategia de Pizarro como futuro gobernador: "se encaminó don Francisco Pizarro al Cuzco, en 1534, y para propiciarse el afecto de los cuzqueños declaró que no venía a quitar a los caciques sus señoríos y propiedades ni a desconocer sus preeminencias" (Palma 1863d: 314). Los oposición entre De Soto y Pizarro juega un papel clave en el transcurso narrativo de esta tradición.

Palma indica que inmediatamente después de la ejecución del inca, Pizarro nombró sucesor a Manco Inca: "castigado ya en Cajamarca con la muerte el usurpador asesino del legítimo Inca Huáscar, se proponía a entregar la insignia imperial al Inca Manco" (Palma 1863d: 314). Manco Inca, no obstante, terminará por sublevarse ante los españoles, y escaparse posteriormente a Vilcabamba. La actitud de Manco Inca se diferencia bastante de las imágenes de docilidad transmitidas por otros escritos. Aunque no siempre se hable de ellas, las sublevaciones indígenas han estado presentes desde el inicio de la colonia: "las poblaciones andinas simplemente se han resistido, mayoritaria y abrumadoramente, a seguir ocupando el lugar subordinado que les deparó el orden oligárquico" (Méndez 1996: 3), aunque estas rebeliones hayan sido, a la larga, del todo infructuosas.

Tiempo después, en su refugio, Manco Inca permite la entrada de varios españoles y les brinda su protección y ayuda. Una noche, en una trifulca, varios españoles echan mano a sus puñales, y como resultado Manco Inca pierde la vida a manos del español Gómez Pérez. Palma finaliza con estas líneas "afirman que el trágico suceso fue motivado por desacuerdo de una jugada de ajedrez" (Palma 1863d: 316). A pesar de lo anecdótico del juego de ajedrez, los elementos de la fatalidad y el destino están explícitamente planteados por el tradicionista: "Estaba escrito que, como el Inca Atahualpa, la afición al ajedrez había de serle fatal al Inca Manco" (Palma 1863d: 315).

Esta última tradición está temáticamente vinculada con la primera, "Palla Huarcuna". En "Palla Huarcuna" hay un destino inevitable: la con- 
quista del Perú. Y en "Los incas ajedrecistas" se cumple ese destino. La caída de Atahualpa es el fin del Tahuantinsuyo. También en esta tradición hay un destino que se cumple, la muerte violenta de Atahualpa precede a la muerte violenta de su sucesor, es decir, el fin del linaje de los incas es inevitable.

Como ya fue explicado previamente, tanto para los primeros exploradores como para los conquistadores, la imposición de la religión en América era necesaria. Las acciones de los españoles quedan justificadas y legitimadas porque, al fin y al cabo, han salvado las almas de los indios y con la ayuda divina los han ayudado a combatir contra el demonio. Cieza, por ejemplo, reconoce con satisfacción casos como el siguiente: "Y así, en estos tiempos ya aborrecen al demonio, y en muchas partes que era estimado y venerado es aborrecido y detestado como malo" (Cieza 1985: 168). Asimismo, el cronista reitera una y otra vez lo siguiente: "y miran en prodigios y señales y guardan supersticiones las que el demonio les manda" (Cieza 1985: 81). La misión principal de los españoles, el objetivo primario, es la "conversión de las gentes de todas aquellas provincias y reinos" (Colón 1989: 41); esta meta terminará, sincretismo religioso aparte, por cumplirse. La conquista, en este sentido, quedará legitimada.

Si bien antes el diablo era el enemigo, en la época de Palma el discurso que prima es el de la modernidad y el progreso. También, en este sentido, se busca un triunfo similar al obtenido por los españoles durante la conquista. Las siete tradiciones analizadas tienen diversos puntos en común. Por un lado transmiten la opinión y los puntos de vista de Palma; por otro lado, también reflexionan y permiten reflexionar sobre la representación literaria de lo incaico y lo andino. "Es interesante notar que el tono humorístico frecuente en Palma no aparece en estas tradiciones, que son más bien poemáticas y exaltan el heroísmo y la nobleza incaica" (Meléndez 1970: 197), aunque muchas de ellas incluyen apuntes irónicos.

Indudablemente, Palma ha contribuido en gran medida con la elaboración de la postura moderna en relación a lo incaico. Es evidente el respeto que tiene Palma por los incas como civilización de la antigüedad; algo lógico si se tiene en cuenta la influencia del romanticismo. Pero para 
él pertenecen a un pasado ya desaparecido, que no guarda ninguna relación ni con el presente ni con el futuro de la patria peruana.

La comunidad imaginada es algo que se construye, que se crea y, por supuesto, es algo en lo que se cree. Obras como la del insigne tradicionista ayudaron a construir y crear la nación peruana en una época clave. Pero también, en cierto modo, permitió que los nuevos ciudadanos del Perú se concentraran exclusivamente en un modelo de progreso que provenía de países más desarrollados. La consecuencia de esta mirada ha sido la pérdida de interés en la cultura autóctona del Perú. "Las ideas decimonónicas de progreso, el positivismo y el desarrollo de la biología al servicio del racismo, se harían sentir con el correr del siglo en nuestro medio e influirían para dar 'solidez científica' a esa ideología de desprecio y segregación del indio" (Méndez 1996: 20).

Palma llega a incluir al incario, aunque brevemente, en sus tradiciones. Pero se podría decir que permanentemente excluye al indígena. Crea la imagen de un pasado glorioso pero no parece creer que este pasado tenga relevancia alguna en la época en la que vive. La consolidación de una literatura nacional trae consigo apenas un vistazo al mundo incaico y su posterior confinamiento al área prescindible de las fábulas anecdóticas.

En su "Preludio obligado", Palma afirma lo siguiente: "De incásica huaca yo sé los secretos" (Palma 1863c: 56). No obstante, el autor maneja el tema del incario sin conferirle mayor profundidad. La visión de modernidad que se compartía en todos los países hispanoamericanos estaba ligada a una elite criolla o mestiza, que la mayor parte de las veces no tenía ningún interés en las culturas o etnias dominadas siglos atrás por los conquistadores europeos. Al menos Palma le presta algo de atención al pasado incaico, pero es evidente que este pasado no forma parte del proyecto modernizador del país.

En conclusión, tal como fue explicado previamente, la literatura contribuirá en gran medida a la creación de una comunidad imaginada, "el discurso criollo fue un discurso que al no reconocer en los indios capacidad para expresarse y representarse por sí mismos, les negaba la personalidad, atribuyéndoles, a cambio, una imaginada" (Méndez 1996: 25). 
Mediante la búsqueda constante de un pasado incaico glorioso, la elite criolla se imagina a sí misma, pero en ese mismo proceso, al indígena se le arrebata toda posibilidad de vincularse con dicho pasado.

También sería útil recordar que los siete textos seleccionados para este artículo pueden entenderse como una suerte de síntesis y conclusión de la tradición literaria que tuvo su origen siglos antes del nacimiento de Ricardo Palma. Si bien los incas serán un tema constante en la historia, ya no lo serán en la literatura. "Esta recurrencia al simbolismo inca y la apelación a una retórica de exaltación del pasado imperial por parte de los criollos se hizo aún más evidente en la época de la independencia. Basadre ha aludido al fenómeno como un primer indigenismo. Otros hablan de incaísmo" (Méndez 1996: 20). Aunque Palma escribe sus tradiciones años después de la independencia, sigue sintiendo la necesidad de exaltar un pasado imperial que nunca experimentó en persona, pero que sí imaginó e idealizó en numerosas ocasiones.

A partir de Palma, ya no se puede hablar de obras literarias que representan lo incaico sino de literatura indianista y posteriormente indigenista. Tradiciones peruanas marca un antes y un después en el devenir literario del Perú.

\section{BIBLIOGRAFÍA}

ANDERSON, BENEDICT. Imaginated Communities: Reflections on the Origin and Spread of Nationalism. Londres: Verso, 2006 [1993].

Cieza de León, Pedro. La crónica del Perú. 1553. Pedro Texeira (ed). Madrid: Sarpe, 1985.

Colón, CRISTÓBAL. "Carta al escribano de ración Luis de Sant'Angel". The Spanish Letter of Columbus to Louis de Sant'Angel. 1492-1992: Re/ Discovering Colonial Writings. Minnesota: University of Minnesota Press, 1989. 425-436.

Sarpe, 1985. 
MELÉNDEZ, CONCHA. La novela indianista en Hispanoamérica (18321889). México: Editorial Cordillera, 1970.

MÉNDEZ, CECILIA. "Incas sí, indios no. Apuntes para el estudio del nacionalismo criollo en el Perú". Lima: Instituto de Estudios Peruanos, 1996.

Nebrija, Antonio. Gramática de la lengua castellana. 1492. Madrid: Editora Nacional, 1980.

PALMA, RICARDO. Tradiciones peruanas. T. I. 1863a. Luciano Ampuero C. (ed.). Lima: Ediciones Culturales, 1973.

Tradiciones peruanas. T. II. 1863b. Luciano Ampuero C. (ed.). Lima: Ediciones Culturales, 1973.

Tradiciones peruanas. T. III. 1863c. Luciano Ampuero C. (ed.). Lima: Ediciones Culturales, 1973.

. Tradiciones peruanas. T. V. 1863d. Luciano Ampuero C. (ed.). Lima: Ediciones Culturales, 1973.

PASTOR, BeATRIz. "Cristóbal Colón y la definición del botín americano". Discurso narrativo de la conquista de América. La Habana: Casa de las Américas, 1983, pp. 17-109. 